\title{
Lettuce cultivation submitted to mulching treatments under open environment
}

\author{
Karin DP Silva ${ }^{1}$; Rivanildo Dallacort ${ }^{1}$; Adalberto Santi ${ }^{2}$ \\ ${ }^{1}$ Universidade do Estado de Mato Grosso (UNEMAT), Tangará da Serra-MT, Brasil; karin_tga@hotmail.com; rivalnildo@unemat.br; \\ ${ }^{2}$ Universidade Federal de Mato Grosso (UFMT), Tangará da Serra-MT, Brasil; adalbertosanti@unemat.br
}

\begin{abstract}
The authors aimed to evaluate the behavior of lettuce (Lactuca sativa), cv. Solaris, submitted to mulching in open environment. The experiment was carried out from April to June 2012, in the experimental area at Universidade do Estado de Mato Grosso, in Tangará da Serra, Brazil. The experiment was conducted on the field, being the experimental design completely randomized with six treatments and four replicates. The treatments consisted of the mulching types: black polyethylene, white polyethylene, black TNT, white TNT, rice husk and one treatment without mulching (bare soil). The evaluated traits were plant and stalk diameter, length of the stalk, total and commercial number of leaves, total and commercial fresh matter. The use of mulching with white polyethylene and rice husk favored the production of lettuce in tropical environment, obtaining the highest averages for the production variables total fresh matter (322.55 and $304.80 \mathrm{~g} / \mathrm{plant}$, respectively), commercial fresh matter (276.74 and $274.54 \mathrm{~g} /$ plant, respectively), total number of leaves (26.4 and 25.7 leaves, respectively), number of commercial leaves (21.7 and 22.1 leaves, respectively) and stalk length (5.48 and 5.79 $\mathrm{cm}$, respectively).
\end{abstract}

Keywords: Lactuca sativa, mulching, cultivation techniques.

\section{RESUMO}

Cultivo de alface submetido a coberturas de solo em ambiente aberto

O objetivo do estudo foi avaliar o comportamento da alface (Lactuca sativa), cv. solaris, submetido a coberturas de solo em ambiente aberto. O experimento foi realizado nos meses de abril a junho de 2012, na área experimental da Universidade do Estado de Mato Grosso (UNEMAT), Campus de Tangará da Serra-MT. $\mathrm{O}$ experimento foi realizado em campo aberto, em delineamento experimental de blocos casualizados, com seis tratamentos e quatro repetições. Os tratamentos foram representados pelas seguintes coberturas: polietileno preto, polietileno branco, TNT preto, TNT branco, casca de arroz e um tratamento em solo sem cobertura. As características avaliadas foram o diâmetro do caule e da planta, comprimento do caule, número de folhas totais e comerciais, massa fresca total e comercial. O uso de cobertura do solo com polietileno branco e casca de arroz foram os mais favoráveis à produção de alface em ambiente tropical, obtendo-se as maiores médias para as variáveis de produção matéria fresca total $(322,55$ e 304,80 $\mathrm{g} /$ planta, respectivamente), massa fresca comercial $(276,74 \mathrm{e}$ $274,54 \mathrm{~g} /$ planta, respectivamente), número total de folhas $(26,4 \mathrm{e}$ 25,7 folhas, respectivamente), número de folhas comerciais $(21,7 \mathrm{e}$ 22,1 folhas, respectivamente) e, comprimento do caule (5,48 e 5,79 $\mathrm{cm}$, respectivamente).

Palavras-chave: Lactuca sativa, "mulching", técnicas de cultivo.

\section{Received on August 16, 2016; accepted on February 24, 2017}

L ettuce (Lactuca sativa) is one of the most important vegetable crops grown worldwide, being commercialized, most part, in natura (Sala, 2011). These days, lettuce is produced throughout the Brazilian territory, considering that this production is basically influenced by the weather, which increases the risk of losses to producers, besides showing short vegetative cycle and the need of intensive cultural practices (Rodrigues et al., 1997).

In Brazil, the production, in great majority, is in large urban centers, due to the losses of the product during commuting and storage. According to IBGE (2006), the State of São Paulo produces about 173,000 tons of lettuce in an area of 7,859 hectares, employing about 6,360 people. Lettuce is easy to commercialize and that is the main reason for the data mentioned above (Meirelles, 1998; Henz \& Suinaga, 2009).

Nowadays, four production systems, at least, are adopted in Brazil: conventional cultivation, organic cultivation, protected cultivation on soil and lettuce cultivated hydroponically in a protected environment. Thus, studies on production in the open area are of great importance, due to some difficulties of some production sectors in installing and developing such techniques, since traditional protected cultivation requires an expensive structure (Filgueira, 2008).

In order to reduce costs and for good market acceptance, the producers seek to adopt new production techniques. The most commonly used technique to cultivate lettuce is mulching, since it 
has several advantages to soil and plant, such as the reduction in competition with weeds, conservation of soil moisture and temperature, reduction of erosion and nutrient leaching. Thus, the authors provide more favorable conditions for plant development and a quality product with lower amounts of agrochemicals, benefiting the producer and consumer (Rodrigues et al., 2009).

Mulching is an ancient horticultural technique, being used for the very first time in strawberry crop, with straw and other organic residues; however, with the advent of plastic, this technique has been used on large scale worldwide due to its several advantages (Goto, 1997).

According to Carvalho et al. (2005), the application of plastic covers can provide a production of better quality in certain regions, since these covers avoid direct contact of the plant with the soil, providing a more favorable environment for plant development. In contrast, using plastic covers in hot climate regions may increase soil temperature, which is harmful to plant development, mainly, in the initial phase, right after the transplanting.

Besides influencing the soil temperature, mulching avoids formation of clods among leaves and their direct contact with soil. Thus, the producers do not need to wash the plants after harvesting. It also provides easier management, making a better quality final product, with better visual aspect for commercializing (Reghin et al., 2002b).

Given the above, the authors aimed to evaluate lettuce plant submitted to mulching in open environment.

\section{MATERIAL AND METHODS}

The experiment was carried out at Universidade do Estado de Mato Grosso, campus of Tangará da Serra, Mato Grosso State, Brazil (14'39'S; $\left.57^{\circ} 25^{\prime} \mathrm{W}\right)$, from April to June, 2012. The local climate is classified as mesothermic humid tropical (AW), high temperatures with summer rains and dry winter, average annual rainfall is 1,404 $\mathrm{mm}$ and average annual air temperature of $24.6^{\circ} \mathrm{C}$ (Dallacort et al., 2011). The soil of the area is classified as Red Latosol (Embrapa, 2013).

The experimental design was of randomized blocks, six treatments and four replicates. The treatments consisted of black TNT (nonwoven fabrics), white TNT, black polyethylene, white polyethylene, rice husk and one treatment without mulching (bare soil). The plots consisted of three rows of 3.0 $\mathrm{m}$, spacing $0.3 \mathrm{~m}$ between rows and 0.3 $\mathrm{m}$ between plants.

Chemical fertilization consisted of $150 \mathrm{~kg} / \mathrm{ha}$ of $\mathrm{N}, 400 \mathrm{~kg} / \mathrm{ha}$ of $\mathrm{P}_{2} \mathrm{O}_{5}$ and $120 \mathrm{~kg} / \mathrm{ha}$ of $\mathrm{K}_{2} \mathrm{O}$, in the form of urea, single superphosphate and potassium chloride, respectively. The fertilizer was divided, applying in the transplanting $20 \%$ of $\mathrm{N}, 100 \%$ of $\mathrm{P}$ and $20 \%$ of $\mathrm{K}$ between the rows. At 15 days after transplanting (DAT), the authors applied $20 \%$ of $\mathrm{N}$ and $20 \%$ of $\mathrm{K}$ dissolved in 10 liters of water, with the aid of a watering can; at 30 and 40 DAT $30 \%$ of $\mathrm{N}$ and $30 \%$ of $\mathrm{K}$ dissolved in 10 liters of water, according to Fontes, (1999).

In the harvest, at $49 \mathrm{DAT}$, four plants per replicate were evaluated, observing the circumference diameter of the plant (DP) using a ruler, from one end to the other. In order to determine the total fresh matter (MFT), the plants were cut to the ground and their leaf matter was weighed using a precision scale. The commercial fresh matter (MFC) corresponded to the leaf matter which presented good visual aspect for commercialization. Stalk length (CC) and diameter (DC) were obtained through removing all the leaves evaluated, then measured with the aid of a digital caliper. The number of commercial leaves (NFC) was expressed by counting the leaves which showed good aspect for commercialization. For the total number of leaves (NFT), the authors considered all the leaves of the selected plants.

The experimental data were submitted to analysis of variance, in which the averages of mulching were compared by Tukey test, at 5\% probability, using the statistical program SISVAR (Ferreira, 2008).

\section{RESULTS AND DISCUSSION}

According to the results obtained in this study, the authors noticed significant effect of mulching for all treatments.

For DP, the treatment with white polyethylene resulted in $35.50 \mathrm{~cm}$, but it did not show any statistically significant differences from the treatment with rice husk $33.85 \mathrm{~cm}$ and black TNT 32.93 $\mathrm{cm}$ (Table 1). The plants submitted to the treatment with black polyethylene resulted in lower average plant diameter, $29.90 \mathrm{~cm}$. Possibly, the heating on the canvas surface due to its high absorptivity, caused plants to burn in the initial growing phase, influencing on the development during the cycle (Ribeiro, 2012).

Evaluating DC, the authors noticed that the treatment with black polyethylene resulted in the lowest value $(1.86 \mathrm{~cm})$, differing statistically only from white polyethylene, (2.66 $\mathrm{cm}$ ) (Table 1), corroborating the results obtained by Andrade Junior et al. (2005), who did not find any significant difference among the five mulching types analyzed (coffee husk, rice husk, dry brachiaria grass, black plastic and

Table 1. Plant diameter (DP), stalk diameter (DC) and stalk length (CC) of lettuce (Lactuca sativa) under different mulching types. Tangará da Serra, UNEMAT, 2012.

\begin{tabular}{llll}
\hline Mulching types & DP $(\mathbf{c m})$ & DC $(\mathbf{c m})$ & $\mathbf{C C}(\mathbf{c m})$ \\
\hline Black TNT & $32.93 \mathrm{abc}$ & $2.34 \mathrm{ab}$ & $4.37 \mathrm{bc}$ \\
White TNT & $30.73 \mathrm{~cd}$ & $2.09 \mathrm{ab}$ & $4.45 \mathrm{bc}$ \\
Black polyethylene & $29.90 \mathrm{~d}$ & $1.86 \mathrm{~b}$ & $3.89 \mathrm{c}$ \\
White polyethylene & $35.50 \mathrm{a}$ & $2.66 \mathrm{a}$ & $5.48 \mathrm{a}$ \\
Rice husk & $33.85 \mathrm{ab}$ & $2.47 \mathrm{ab}$ & $5.79 \mathrm{a}$ \\
Without cover (bare soil) & $31.45 \mathrm{bcd}$ & $2.16 \mathrm{ab}$ & $4.91 \mathrm{ab}$ \\
\hline CV $(\%)$ & 3.54 & 12.80 & 8.75 \\
\hline
\end{tabular}

Averages followed by the same letters do not differ, Tukey test, $5 \%$. 
Table 2. Total number of leaves (NFT) and number of commercial leaves (NFC), of lettuce grown under different mulching types. Tangará da Serra, UNEMAT, 2012.

\begin{tabular}{lcl}
\hline Mulching types & NFT & NFC \\
\hline Black TNT & $22.2 \mathrm{~b}$ & $19.2 \mathrm{~b}$ \\
White TNT & $22.9 \mathrm{~b}$ & $19.3 \mathrm{~b}$ \\
Black polyethylene & $18.7 \mathrm{c}$ & $14.0 \mathrm{c}$ \\
White polyethylene & $26.4 \mathrm{a}$ & $21.7 \mathrm{a}$ \\
Rice husk & $25.7 \mathrm{a}$ & $22.1 \mathrm{a}$ \\
Without cover & $22.5 \mathrm{~b}$ & $18.1 \mathrm{~b}$ \\
\hline CV $(\%)$ & 5.32 & 5.04 \\
\hline
\end{tabular}

Averages followed by the same letters do not differ, Tukey test, $5 \%$.

Table 3. Total fresh mass (MFT) and commercial fresh mass (MFC) of lettuce grown under different mulchingt types. Tangará da Serra-MT, UNEMAT, 2012.

\begin{tabular}{lcc}
\hline Mulching types & MFT (g/plant) & MFC (g/plant) \\
\hline Black TNT & $252.71 \mathrm{ab}$ & $230.68 \mathrm{ab}$ \\
White TNT & $232.08 \mathrm{bc}$ & $209.27 \mathrm{~b}$ \\
Black polyethylene & $161.13 \mathrm{c}$ & $134.98 \mathrm{c}$ \\
White polyethylene & $322.55 \mathrm{a}$ & $276.74 \mathrm{a}$ \\
Rice husk & $304.80 \mathrm{a}$ & $274.54 \mathrm{a}$ \\
Without cover & $271.51 \mathrm{ab}$ & $247.16 \mathrm{ab}$ \\
\hline CV $(\%)$ & 9.26 & 12.01 \\
\hline
\end{tabular}

Averages followed by the same letters do not differ, Tukey test, $5 \%$.

without cover) for the lettuce cultivars Regina and Elisa.

For $\mathrm{CC}$, the treatment with rice husk and white polyethylene resulted in the highest averages for this trait, 5.79 and $5.48 \mathrm{~cm}$, respectively, and they did not show any statistically differences from the treatment with soil without cover, $4.91 \mathrm{~cm}$ (Table 1). The authors observed that plants with the highest stalk length grown under white polyethylene and rice husk obtained the largest diameters. Reghin et al. (2002a) found opposite results for this variation, in which the black mulching promoted the highest average in relation to the other evaluated treatments (rice straw and bare soil), according to the authors, due to microclimate provided by plastic.

The results for NFT and NFC were similar, considering that the treatment of white polyethylene showed the largest number of leaves (26.4 and 21.7 , respectively), statistically similar to the treatment of rice husk (25.7 and 22.1 , respectively). The plants covered with black polyethylene resulted in the lowest values for NFT (18.7) and NFC
(14.0), whereas the treatment with white polyethylene was $41.2 \%$ higher in relation to black polyethylene for NFT. In relation to NFC, the treatment with rice husk was $57.8 \%$ higher than the treatment with black polyethylene (Table 2). The treatments which provided plants with the highest NFT also resulted in the highest DP. Thus, the higher DP and CC higher the NFT.

Yuri et al. (2011) presented opposite results in relation to strawberry crop when comparing the use of plastic covers, in which the treatment with black polyethylene showed a larger number of leaves in relation to white polyethylene.

The highest values for MFT were obtained with treatments with white polyethylene, rice husk, soil without cover and black TNT, 322.55; 304.80; $271.51 ; 252.71 \mathrm{~g} / \mathrm{plant}$, respectively. The lowest average was obtained through treatment with black polyethylene $161.13 \mathrm{~g} /$ plant (Table 3). Carvalho et al. (2005), in a experiment carried out in the municipality of Ji-Paraná-RO, evaluated the accumulated fresh mass, in which the control treatment (without cover) provided the lowest average, differing from the other treatments evaluated. According to Reghin et al. (2002b), the treatment with rice husk and bare soil showed the lowest average values comparing to the treatment with black plastic, since they promote weed development, consequently, competition for water, light and nutrients interfering with the crop growth.

In relation to MFC, similar to MFT, the highest values were obtained through treatments with white polyethylene $(276.74 \mathrm{~g} /$ plant $)$, rice husk (274.54 g/plant), soil without cover (247.16 $\mathrm{g} / \mathrm{plant})$ and black TNT (230.68 $\mathrm{g} /$ plant), not differing statistically among them (Table 3). Tosta et al. (2010), also observed for cv. Babá de Verão the highest commercial mass and productivity, with black mulching. According to the authors, this cover decreases the incidence of weeds in soil providing more favorable conditions for plant development.

Leaf cultivation under polyethylene cover shows critical phase after seedling transplanting due to the direct incidence of the sun's rays on the plastic, which raises the temperature to critical levels for the plants. However, during the plant development the shading effect of the plastic provides a more favorable environment, for plant development, reducing weed competition. Therefore, the use of white polyethylene and rice husk as mulching are favorable for lettuce growing.

\section{ACKNOWLEDGEMENTS}

The authors thank to FAPEMAT, Foundation for Research Support and Innovation of Mato Grosso (Fundação de Amparo a Pesquisa do Estado de Mato Grosso), for scholarship granted.

\section{REFERENCES}

ANDRADE JÚNIOR, VC; YURI, JE; NUNES, UR; PIMENTA, FL; MATOS, CSM; FLORIO, FCA; MADEIRA, DM. 2005. Emprego de tipos de cobertura de canteiro no cultivo da alface. Horticultura Brasileira 23: 899-903.

CARVALHO, JE; ZANELLA, F; MOTA, JH; LIMA, ALS. 2005. Cobertura morta do solo 
no cultivo de alface cv. Regina 2000, em Ji-Paraná-RO. Ciências Agrotécnicas 29: 935-939.

DALLACORT, R; MARTINS, JA; INOUE, MH; FREITAS, PSL; COLLETI, AJ. 2011. Distribuição das chuvas no município de Tangará da Serra, médio norte do Estado de Mato Grosso, Brasil. Acta Scientiarum 33: 193-200.

EMBRAPA, Centro Nacional de Pesquisa de Solos. 2013. Sistema brasileiro de classificação de solos. Rio de Janeiro: EMBRAPA Solos. 306p.

FERREIRA, DF. 2008. SISVAR: Um programa para análise e ensino de estatística. Revista Symposium 6: 36-41.

FILGUEIRA, FAR. 2008. Novo manual de olericultura. Viçosa: UFV. 412p.

FONTES, PCR. 1999. Alface In: RIBEIRO, AC; GUIMARÃES, PTG; ALVAREZ, VVH (eds). Recomendações para o uso de corretivos e fertilizantes em Minas Gerais. Viçosa: Comissão de Fertilidade do Solo de Estado de Minas Gerais 177p.

GOTO, R. 1997. Plasticultura nos trópicos: uma avaliação técnico-econômica. Horticultura Brasileira 15: 163-165.

HENZ, GP; SUINAGA, F. 2009. Tipos de alface cultivados no Brasil. Brasília: Embrapa (Comunicado técnico 75).

IBGE. Censo agropecuário: Sudoeste. 2006. Rio de Janeiro. Disponível em: <www.sidra.ibge. gov. $b r>$. Acessado em 07 de outubro de 2012.

MEIRELLES, JCS. 1998. Classificação de alface. São Paulo: Horti \& Fruti (Folder).

REGHIN, MY; PURISSIMO, C; FELTRIM, AL; FOLTRAN, MA. 2002a. Produção de alface utilizando cobertura do solo e proteção das plantas. Scientia Agraria 3: 69-77.

REGHIN, MY; PURÍSSIMO, C; PRIA, MD; FELTRIM, AL; FOLTRAN, MA. 2002b. Técnicas de cobertura de solo e de proteção de plantas no cultivo da alface. Horticultura Brasileira 20: 1-5.

RIBEIRO, AJ. 2012. Efeito do "mulching" com malha de sombreamento no cultivo de alface. Florianópolis: UFSC. 30p. (Monografia graduação).

RODRIGUES, AB; MARTINS, MIEG; ARAÚJO,
JAC. 1997. Avaliação econômica da produção de alface em estufa. Informações Econômicas 27: 27-37.

RODRIGUES, DS; NOMURA, ES; GARCIA, VA. 2009. Coberturas de solo afetando a produção de alface em sistema orgânico. Revista Ceres 56: 332-335.

SALA, FC. 2011. Melhoramento genético de alface. IN: CONGRESSO BRASILEIRO DE OLERICULTURA, 51. Horticultura Brasileira 29. Viçosa: ABH. p. 5813-5827.

TOSTA, PAF; MENDONÇA, V; TOSTA, MS; MACHADO, JR; TOSTA, JS; MEDEIROS, LF. 2010. Utilização de coberturas de solo no cultivo de alface 'Babá de Verão' em Cassilândia (MS). Revista Brasileira de Ciências Agrárias 5: 85-89.

YURI, JE; RESENDE, GM; COSTA, ND; MOTA, JH. 2011. Uso de mulching como cobertura de solo para o cultivo do morangueiro. In: CONGRESSO BRASILEIRO DE OLERICULTURA, 51. Anais... Viçosa: ABH. p.1799-1806. 